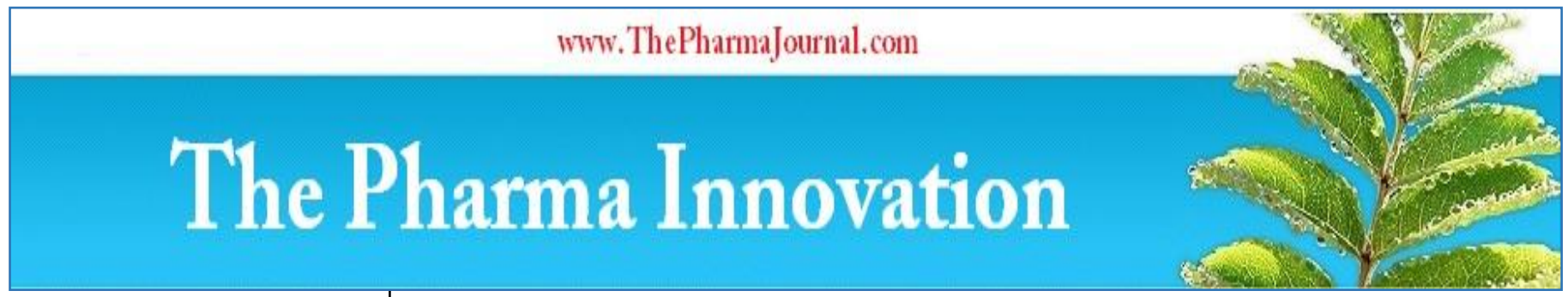

ISSN (E): 2277- 7695

ISSN (P): 2349-8242

NAAS Rating: $\mathbf{5 . 0 3}$

TPI 2021; 10(1): 272-278

(C) $2021 \mathrm{TPI}$

www.thepharmajournal.com

Received: 16-11-2020

Accepted: 18-12-2020

\section{Sindhu A Divakar}

Department of Food Science and Nutrition, University of Mysore, Mysuru, Karnataka, India

\section{Jamuna Prakash}

Department of Food Science and Nutrition, University of Mysore, Mysuru, Karnataka, India
Corresponding Author: Sindhu A Divakar

Department of Food Science and Nutrition, University of Mysore, Mysuru, Karnataka, India

\title{
Quality parameters and shelf stability of millet based 'Khakhra'
}

\section{Sindhu A Divakar and Jamuna Prakash}

DOI: https://doi.org/10.22271/tpi.2021.v10.i1d.5525

Abstract

Millets being rich in nutrients, phytochemicals, antioxidants, dietary fiber, along with a number of health promoting properties, are finding place in the market due to increasing awareness of their goodness among the consumers. Due to lack of information on processing and preparation there has been a very slow rise in its acceptance. Value added products based on millets may mend the gap between consumer acceptance and demand. Hence this study was taken up with an objective to develop khakhra, which are thin crackers, incorporating different millets namely foxtail millet (Setaria italica), finger millet (Eleusine coracana), pearl millet (Pennisetum typhoides) and sorghum (Sorghum bicolor) as variants in wholegrain composite flour. The nutritional composition and shelf-stability was analyzed by using standard protocols. The results revealed that products were high in protein content (11.04-17.54\%), dietary fiber (9.35-13.41\%), antioxidant activity $(14,691.88-2,14,115.53 \mu$ moles equivalent to ascorbic acid/g), total phenols and flavonoid contents. Sensory evaluation showed that finger millet incorporated product had low acceptability compared to the rest of the millets used. The free fatty acid, peroxide value and microbial load were well within safe limits for up to 90 days. In conclusion, a shelf-stable traditional ready-to-eat snack can be developed using different millets which can be used as a functional food.

Keywords: Millets, antioxidants, ready-to-eat, functional foods

\section{Introduction}

In recent times there has been a tremendous shift in food consumption pattern due to increasing awareness of the how refined flours have an adverse effect on health outcome. Consumers are becoming more health conscious and are getting to know more about what type of food is getting into their system by getting acquainted with the nutritional quality of the products consumed $\left.{ }^{[1,} 2\right]$. Hence, traditionally consumed cereals, millets, legumes and wholegrains are gaining popularity among consumers. Perspectives towards foods have changed over the decade and acceptance of wholegrain foods as not just nutritious but also as something which improves health and lowers risk of health problems ${ }^{[3]}$.

Wholegrains are rich in nutrients, antioxidants, phytochemicals and dietary fiber which have protective effects against diseases ${ }^{[4]}$. Very few of the cereals and millets consumed in India such as whole wheat, finger millet, pearl millet, sorghum and brown rice are considered as wholegrains ${ }^{[5]}$. Phenolics, flavonoids and anthocyanins present in wholegrain cereals, legumes and millets also act as potential antioxidants ${ }^{[6]}$. These indicate wholegrains have free radical scavenging activity in human body when consumed on daily basis and hence act as protective agents against major non-communicable diseases. A study done by Siddiq \& Prakash, ${ }^{[7]}$ found that the antioxidant components were bound to the fiber fraction of the wholegrain foods which were gradually released during the digestion process making them more available to the body.

However, millet and wholegrain based products from either individual grains or in combination are very few. A study on multi millet ready-to-eat extruded snack based on flour blends of finger millet, pearl millet and foxtail millet was reported ${ }^{[8]}$. Traditional snacks available in India are much more nutritious than those commonly available in the market ${ }^{\text {[9] }}$ and Khakhra is one such traditional ready to eat food which originates from the state of Gujrat, India. Khakhras are very thin crackers, crunchy, consumed either as a snack or breakfast item. Gujarat is famous for this snack of course; in recent times it has gained popularity in other parts of the country as well. As these do not require any further processing during consumption, have a long shelf life and are light to weigh, they serve as popular convenient 
snack to be carried during travelling among Indians. These are uniquely hand-made and roasted products, with different varieties available in the market however, most of them do not possess any additional health benefits. Availability of such snack with addition of millets may enhance to the nutritional value and provide health benefits.

Thus, in view of this, the present study made an effort to diversify the utilization of millet and wholegrain based composite flour in the production of khakhras, which were nutritionally rich and possessed health promoting properties. It was further investigated for nutritional composition, antioxidant activity, and shelf-life study.

\section{Materials and Methods}

The raw materials selected for the study were brown rice (Oryza sativa, Navara), finger millet (Eleusine coracana), pearl millet (Pennisetum typhoides) and sorghum (Sorghum bicolor), foxtail millet(Setaria italica), grain amaranth (Amaranthus cruentus, Rajgeera), soyabean (Glycine max), flaxseeds (Linum usitatissimum) and black cumin (Nigella sativa), spices like turmeric, red chilli powder, carom seeds, cumin seeds and salt. These ingredients were purchased from local certified organic shop in one batch, cleaned of extraneous mater. Grains used for composite flour formulation was individually oven dried at $60^{\circ} \mathrm{C}$ for $30 \mathrm{mins}$. Composite flours were prepared by blending ingredients in different proportions namely brown rice at $50 \%$, soyabean $15 \%$, amaranth seeds $8 \%$, while flax and black cumin each at $1 \%$. Four different variations were produced by altering the different millets at $25 \%$ namely pearl millet, finger millet, sorghum, and foxtail millet. Spices were added at $2.5 \mathrm{gm}$ each, while $7.5 \mathrm{gm}$ of salt was added for $100 \mathrm{gm}$ of flour used. These ingredients were purchased from local certified organic shop in one batch, cleaned of extraneous matter, grains were oven dried separately and milled. All chemicals used for the study were of analytical grade and purchased from Sd Fine Chemicals, Himedia laboratories, Qualigens Chemicals Ltd., Mumbai, India. Glass double-distilled water was used and all experiments were carried out in triplicate.

\subsection{Preparation of flour and product}

Khakhras were prepared according to fig 1. Four variations were produced by varying the different millet namely pearl millet /bajra khakhra (BK), finger millet/ragi khakhra (RK), sorghum khakhra (SK), and foxtail millet khakhra (FMK).

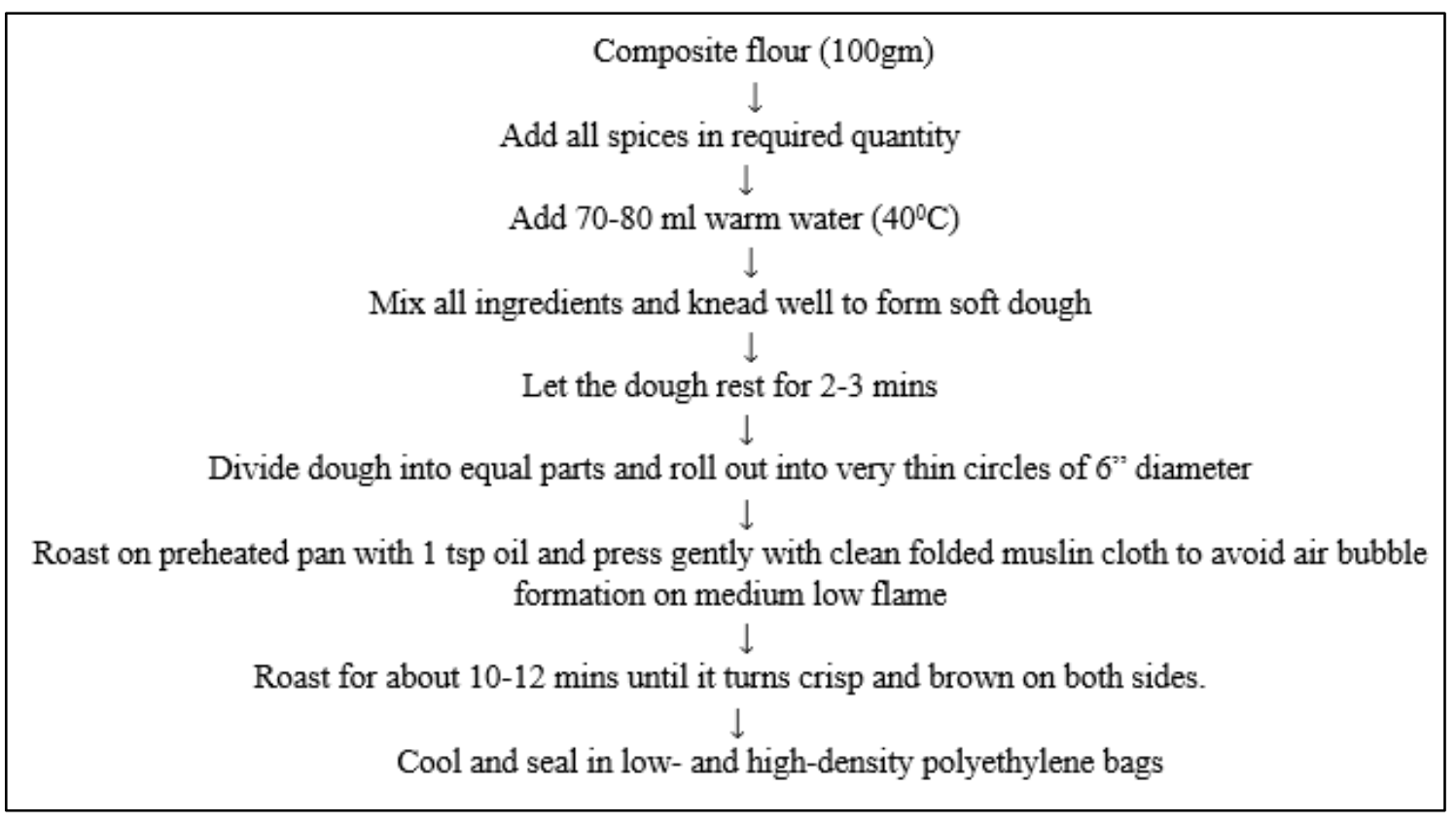

Fig 1: Preparation of khakhra.

\subsection{Analysis of nutritional composition}

The formulated products were analyzed for moisture by oven drying method, fat by solvent extraction by Soxhlet method, protein by Kjeldahl nitrogen distillation and multiplying the nitrogen value with $6.25^{[10,11]}$, total ash by direct incineration, dietary fiber consisting of both insoluble and soluble fibers was estimated by rapid enzymatic assay ${ }^{[12]}$ method, the carbohydrate content was calculated by difference.

\subsection{Analysis of antioxidant activity and Bioactive components}

2.3.1. Total antioxidant activity by Phosphomolybdenum method

This assay is based on the formation of a reduced complex MO (V) by the sample in different extraction media at an acidic $\mathrm{pH}$. The results were expressed as $\mu$ moles of total antioxidant activity per $\mathrm{g}$ of sample ${ }^{[13]}$.

\subsubsection{Analysis of bioactive components}

The different extraction media selected for estimation of polyphenols and flavonoids were water, and methanol. A known amount of sample was mixed with extracting media and shaken for $3 \mathrm{~h}$ which was then filtered through Whatman filter paper No.1. Polyphenols were estimated with FolinCiocalteuo reagent and values expressed as $\mathrm{mg}$ of tannic acid equivalents/100 $\mathrm{g}$ of sample ${ }^{[14]}$. The flavonoid content was estimated using the Dowd method as adapted by ArvouetGrand and others ${ }^{[15]}$ was expressed as $\mathrm{mg}$ of quercetin equivalents per $100 \mathrm{~g}$ of sample.

\subsection{Sensory evaluation}

All the developed products were evaluated by a semi trained panel $(n=20)$. The products were evaluated for Appearance, Texture, Aroma, Taste and Overall acceptability on a ninepoint hedonic scale ${ }^{[16]}$. 


\subsection{Shelf-life study}

The khakhras were packed in Low-Density Polyethylene (LDPE) and High-Density Polyethylene (HDPE) bags, heat sealed and stored at ambient temperature for a period of 90 days. The storage quality of khakhras were evaluated for moisture content, free fatty acid (FFA), peroxide value (PV) ${ }^{[17]}$ and microbial load (pour plate method) ${ }^{[18]}$.

\subsection{Statistical Analysis}

Data presented represents means \pm standard deviation of triplicate measurements. The significant difference comparisons were done by one way analysis of variance (ANOVA), followed by the T-test in SPSS 27.0 and the statistical significance was defined as $\mathrm{P}<0.05$. Students "T" test was used to determine the level of significant difference between two different solvents used in the experiments.

\section{Results and Discussions}

\subsection{Nutritional composition}

The nutritional composition and mineral contents of four experimental varieties of khakhras are presented in Table 1. The analyzed products with moisture content of $6-7 \%$ showed nearly $12-19 \%$ protein content, $11-14 \%$ fat, $10-$ $14 \%$ dietary fiber and $49-57 \%$ carbohydrates content. Each product variant differed significantly in terms of protein, fat, carbohydrate, total dietary fibre and mineral contents. Higher protein content was found in SK $(18.79 \%)$ and BK showed a lower content of $11.76 \%$. Similar findings were obtained in a study where extruded snacks were prepared using flour blend containing sorghum, corn, whey protein isolate and defatted soy with a high protein content of $22 \%{ }^{[19]}$. Fat content was highest in FMK (14.18\%) and lowest in RK (10.69\%) with no significant difference seen among other samples. Ash content and soluble dietary fiber were seen to be non-significant among samples. Insoluble dietary fiber was highest in sample RK, 13.28 and lowest in sample FMK, 8.73. Significant difference among samples existed. Similar to the present study dietary fiber content of $18.40 \%$ was observed in a study done on ready-to-eat processed breakfast cereals based on finger millet ${ }^{[20]}$. Carbohydrate content was estimated by difference and it varied in the range 48.51 to $56.55 \%$. In a study done on masala khakhra prepared by incorporating $60 \%$ of kodo millet showed similar amounts of carbohydrates as in the present study, which was about $56 \%{ }^{[21]}$. It may be noted that among all minerals analyzed, SK was richer in minerals such as iron, phosphorus, zinc and magnesium which were about $12.15 \mathrm{mg} 188 \mathrm{mg}, \quad 3.90 \mathrm{mg}$ and $199 \mathrm{mg} / 100 \mathrm{~g}$ respectively on dry weight basis. Calcium and sodium were noted to be high in finger millet product which was about 188 $\mathrm{mg}$ and $130 \mathrm{mg} / 100 \mathrm{~g}$ respectively on dry weight basis. Lower contents of minerals were found mostly in pearl millet-based product with calcium (127mg), phosphorus $(169 \mathrm{mg})$, zinc(2.67) and magnesium( $160 \mathrm{mg} / 100 \mathrm{~g})$. RK showed the least iron content $(7.53 \mathrm{mg})$ and FMK contained the least sodium content $(115.02 \mathrm{mg})$ per $100 \mathrm{~g}$ product. Composite flour developed by Bolarinwa and others using malted sorghum and soy flour showed an increase in minerals such as iron, calcium, zinc and phosphorus content upon substitution at varied levels ${ }^{[22]}$

Table 1: Nutritional composition of khakhras (per $100 \mathrm{~g}$ )

\begin{tabular}{|c|c|c|c|c|}
\hline Nutrient composition & Pearl millet (BK) & Finger millet (RK) & Foxtail millet (FMK) & Sorghum (SK) \\
\hline Moisture $(\%)$ & $6.03^{\circ} 0.1^{\mathrm{a}}$ & $6.67 \pm 0.26^{\mathrm{a}}$ & $5.77 \pm 0.21^{\mathrm{b}}$ & $6.67 \pm 0.15^{\mathrm{a}}$ \\
\hline Protein(g) & $11.05 \pm 0.49^{\mathrm{c}}(11.76)$ & $13.96 \pm 0.15^{\mathrm{b}}(14.96)$ & $14.64 \pm 0.08^{\mathrm{b}}(15.53)$ & $17.54 \pm 0.97^{\mathrm{a}}(18.79)$ \\
\hline Fat $(\mathrm{g})$ & $11.94 \pm 0.28^{\mathrm{b}}(12.49)$ & $10.31 \pm 0.27^{\mathrm{c}}(10.69)$ & $13.76 \pm 0.36^{\mathrm{a}}(14.18)$ & $12.03 \pm 0.51^{\mathrm{b}}(12.39)$ \\
\hline Total Ash(g) & $3.62 \pm 0.59^{\mathrm{NS}}(3.81)$ & $3.33 \pm 0.31^{\mathrm{NS}}(3.48)$ & $3.59 \pm 0.87^{\mathrm{NS}}(3.71)$ & $3.24 \pm 0.46^{\mathrm{NS}}(3.42)$ \\
\hline Soluble Dietary Fiber(g) & $0.96 \pm 0.01^{\mathrm{NS}}(1.02)$ & $0.99 \pm 0.01^{\mathrm{NS}}(1.07)$ & $1.16 \pm 0.06^{\mathrm{NS}}(1.23)$ & $1.1 \pm 0.18^{\mathrm{NS}}(1.18)$ \\
\hline Insoluble Dietary Fiber(g) & $9.8 \pm 0.09^{\mathrm{c}}(10.43)$ & $12.39 \pm 0.08^{\mathrm{a}}(13.275)$ & $8.22 \pm 0.14^{\mathrm{d}}(8.73)$ & $11.28 \pm 0.1^{\mathrm{b}}(12.085)$ \\
\hline Carbohydrate (g) & 56.55 & 52.41 & 52.82 & 48.51 \\
\hline Iron (mg) & $11.08 \pm 0.01^{\mathrm{b}}(11.79)$ & $7.02 \pm 0.01^{\mathrm{d}}(7.53)$ & $9.14 \pm 0.04^{\mathrm{c}}(9.79)$ & $11.34 \pm 0.01^{\mathrm{a}}(12.15)$ \\
\hline Calcium $(\mathrm{mg})$ & $119 \pm 0.07^{\mathrm{c}}(127)$ & $176 \pm 0.01^{\mathrm{a}}(188)$ & $127 \pm 0.28^{\mathrm{b}}(135)$ & $126 \pm 0.02^{\mathrm{b}}(135)$ \\
\hline Phosphorus (mg) & $159 \pm 0.51^{\mathrm{c}}(169)$ & $164 \pm 0.46^{\mathrm{b}}(176)$ & $162 \pm 0.71^{\mathrm{b}}(172)$ & $180 \pm 1.04^{\mathrm{a}}(193)$ \\
\hline Sodium (mg) & $116.40 \pm 0.44^{\mathrm{b}}(123.88)$ & $121.30 \pm 0.4^{\mathrm{a}}(129.95)$ & $108.39 \pm 0.83^{\mathrm{c}}(115.02)$ & $116.59 \pm 0.43^{\mathrm{b}}(124.91)$ \\
\hline Zinc $(\mathrm{mg})$ & $2.50 \pm 0.13^{\mathrm{b}}(2.67)$ & $3.47 \pm 0.4^{\mathrm{a}}(3.72)$ & $2.74 \pm 0.33^{\mathrm{b}}(2.92)$ & $3.64 \pm 0.0^{\mathrm{a}}(3.9)$ \\
\hline Magnesium $(\mathrm{mg})$ & $151 \pm 0.53^{\mathrm{d}}(160)$ & $178 \pm 0.98^{\mathrm{b}}(190)$ & $170 \pm 0.53^{\mathrm{c}}(180)$ & $186 \pm 1.08^{\mathrm{a}}(199)$ \\
\hline
\end{tabular}

Values are mean \pm standard deviation. Figures in parenthesis represent values in dry matter basis. Values in different supers cripts indicate significant difference among samples on application of Tukey's Test. NS=Not Significant.

\subsection{Antioxidant components and total antioxidant activity}

According to recent development in research understanding suggest that the synergistic effect of the fiber along with phenolic acids in wholegrains may contribute to the many health effects ${ }^{[23-26]}$. Phenolic compounds are well researched due to their bioactive properties and possible health benefits. The antioxidant components (AC) and total antioxidant activity (TAA) of all samples were analyzed in different solvent extracts to understand their potential antioxidant capacity and data are presented in Table 2 . There was a wide variation in total phenol content among different types of samples and extraction media. Higher level of total phenols was seen in methanolic extract with BK (237.78mg/100g). Although cereals and millets are not a good source of flavonoids, the prepared products showed a good amount of flavonoids ranging 85.75 to $553.23 \mathrm{mg} / 100 \mathrm{~g}$. This may be due to the presence of nigella sativa and other spices present in the product ${ }^{[27]}$. Also, a review by $\mathrm{Yao}$ and others done to understand effects on flavonoids in food on health showed that cumin and peppermint were good sources of flavanones namely naringenin and eriodictyol ${ }^{[28]}$. According to Nambiar and others, flavonoids act as powerful antioxidants exerting greater effects than vitamin $\mathrm{C}, \mathrm{E}$, zinc and selenium by preventing oxidized cholesterol formation and preventing from free radical damage ${ }^{[29]}$

Total antioxidant activity also varied among samples in different extraction medium. With highest activity found in BK $(2,14,115.53 \mu$ moles equivalent to ascorbic acid $/ \mathrm{g})$ following the same trend as in total phenols and flavonoids. In the methanolic extract there was not much difference statistically among the other three samples, yet significant differences from one another was seen among samples in 
water as extraction media. A study done to understand the antioxidant activity in pearl millet cultivars, showed that processing and heat treatments increased the flavonoid content and higher antioxidant activity was observed ${ }^{[30]}$.

Table 2: Antioxidant components and antioxidant activity in different extraction media

\begin{tabular}{|c|c|c|c|c|}
\hline Extraction media & Pearl millet (BK) & Finger millet (RK) & Foxtail millet (FMK) & Sorghum (SK) \\
\hline \multicolumn{5}{|c|}{ Total Phenols (mg tannic acid equivalents/100 g) } \\
\hline Methanol & $237.78 \pm 8.17^{\mathrm{a}}$ & $163.02 \pm 4.37^{\mathrm{c}}$ & $159.65 \pm 4.84^{\mathrm{c}}$ & $180.64 \pm 4.6^{\mathrm{b}}$ \\
\hline Aqueous & $62.38 \pm 2.53^{\mathrm{b}}$ & $64.06 \pm 1.84^{\mathrm{ab}}$ & $74.33 \pm 4.72^{\mathrm{a}}$ & $65.29 \pm 5.37^{\mathrm{ab}}$ \\
\hline \multicolumn{5}{|c|}{ Total Flavonoids (mg quercetin equivalents/100 g) } \\
\hline Methanol & $553.25 \pm 3.04^{\mathrm{a}}$ & $208.65 \pm 2.98^{\mathrm{b}}$ & $204.67 \pm 13.04^{\mathrm{ab}}$ & $187.44 \pm 4.14^{\mathrm{c}}$ \\
\hline Aqueous & $115.54 \pm 13.12^{\mathrm{a}}$ & $118.19 \pm 0.99^{\mathrm{a}}$ & $85.72 \pm 10.2^{\mathrm{b}}$ & $98.64 \pm 3.04^{\mathrm{ab}}$ \\
\hline \multicolumn{5}{|c|}{ Total Antioxidant Activity ( $\mu$ moles equivalent to ascorbic acid/g) } \\
\hline Methanol & $2,14,115.53 \pm 2380.27^{a}$ & $1,41,028.51 \pm 11331.36^{b}$ & $1,22,274.35 \pm 203.11^{\mathrm{b}}$ & $1,20,175.51 \pm 2742.66^{\mathrm{b}}$ \\
\hline Aqueous & $22,071.67 \pm 521.15^{\mathrm{a}}$ & $14,691.88 \pm 293.17^{\mathrm{c}}$ & $15,423.78 \pm 1141.48^{\mathrm{d}}$ & $17,366.21 \pm 902.66^{\mathrm{b}}$ \\
\hline
\end{tabular}

Values are mean \pm standard deviation. Values in different superscripts indicate significant difference among samples on application of Tukey's Test.

\subsection{Sensory evaluation}

Table 3 depicts the mean organoleptic scores of khakhras for the characteristics of appearance, colour, texture, aroma, taste and overall acceptability. The difference in sensory scores was found to be statistically significant at 5\% level. Among the four varieties', SK scored high for appearance (7.70), colour (8.17), texture (7.5) and aroma (7.7). While similar scores were seen in sample BK for taste and aroma as SK. Scores for texture were found to be nearly same among samples FMK and SK. Overall acceptability of the khakhras showed no significant difference among samples FMK, SK and BK while RK was least accepted and was significantly different from the rest of the samples. A study on organoleptic, nutritional characteristics and storage stability of value added khakhra using kodomillet, showed that up to $60 \%$ incorporation of kodo millet flour was highly acceptable [21]. While another study on khakhras using barnyard millet, wheat flour, soyabean flour and green gram dal flour, concluded significantly higher $(p<0.05)$ values for all the sensory parameters in $10 \%$ pulse incorporated khakhras ${ }^{[31]}$.

Table 3: Mean Organoleptic Scores of Khakhras

\begin{tabular}{|c|c|c|c|c|}
\hline Sensory quality & BK & RK & FMK & SK \\
\hline Appearance & $8.06 \pm 0.37^{\mathrm{a}}$ & $7.15 \pm 0.34^{\mathrm{b}}$ & $8.00 \pm 0.62^{\mathrm{a}}$ & $7.70 \pm 0.48^{\mathrm{a}}$ \\
\hline Colour & $7.65 \pm 0.39^{\mathrm{b}}$ & $6.85 \pm 0.34^{\mathrm{c}}$ & $7.78 \pm 0.44^{\mathrm{ab}}$ & $8.17 \pm 0.41^{\mathrm{a}}$ \\
\hline Texture & $7.40 \pm 0.49^{\mathrm{a}}$ & $6.70 \pm 0.48^{\mathrm{b}}$ & $7.50 \pm 0.47^{\mathrm{a}}$ & $7.50 \pm 0.41^{\mathrm{a}}$ \\
\hline Aroma & $7.70 \pm 0.4^{\mathrm{a}}$ & $6.80 \pm 0.26^{\mathrm{b}}$ & $7.30 \pm 0.42^{\mathrm{a}}$ & $7.70 \pm 0.42^{\mathrm{a}}$ \\
\hline Taste & $7.75 \pm 0.34^{\mathrm{a}}$ & $6.75 \pm 0.26^{\mathrm{c}}$ & $7.55 \pm 0.5^{\mathrm{ab}}$ & $7.17 \pm 0.33^{\mathrm{bc}}$ \\
\hline Overall Acceptability & $7.30 \pm 0.46^{\mathrm{a}}$ & $6.75 \pm 0.26^{\mathrm{b}}$ & $7.38 \pm 0.46^{\mathrm{a}}$ & $7.44 \pm 0.44^{\mathrm{a}}$ \\
\hline
\end{tabular}

Values are mean \pm standard deviation. Values in different superscripts indicate significant difference among samples on application of Tukey's Test (Horizontal rows).

\subsection{Peroxide value, free fatty acid and moisture content}

Free fatty acids, peroxide value and moisture content of developed products from initial to 90days of storage in different packaging material were analyzed. These parameters help determine the keeping quality of the developed product. While moisture is one of the important factors responsible for the deterioration of quality of the products during storage, it was found that there was not much difference among the varieties, while very slight difference appeared among the packaging material. Free fatty acid value (FFA) of developed

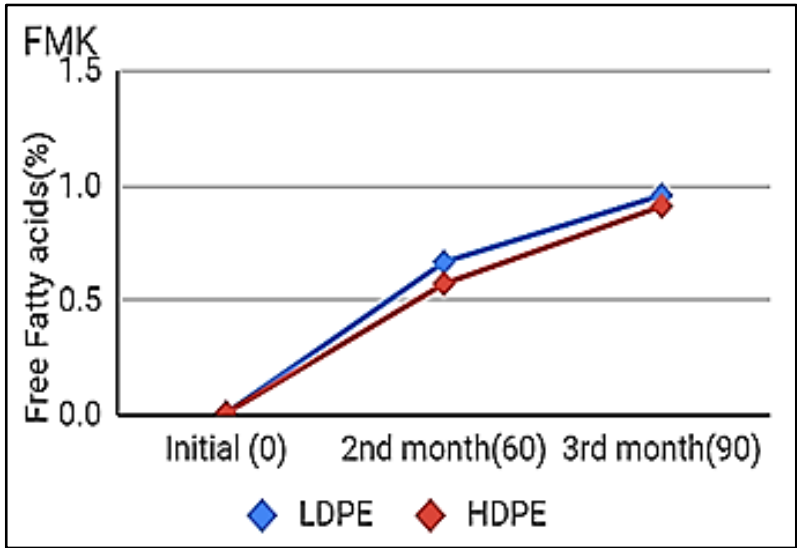

products from initial to 90 days of storage are as seen in the Fig 2. Free fatty acids increased with increase in number of days, it varied nearly about 0.01 to $1.05 \%$ in low density polyethylene (LDPE) and 0.01 to $0.99 \%$ in high density polyethylene (HDPE). Highest free fatty acid value was seen in sample BK $(1.06 \%)$ stored in LDPE. Between LDPE and HDPE pouches, BK showed significantly higher values on $90^{\text {th }}$ day, 1.05 and $0.99 \%$ respectively. There was no significant difference observed in FFA between the two types of packaging material.

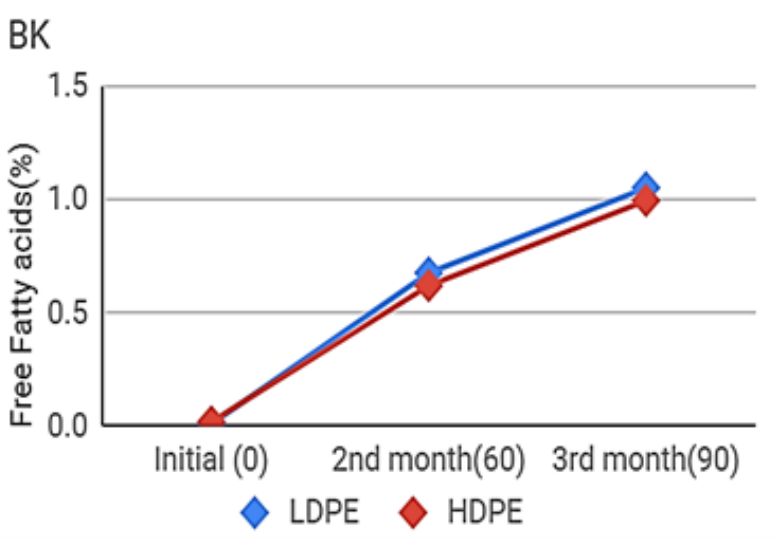



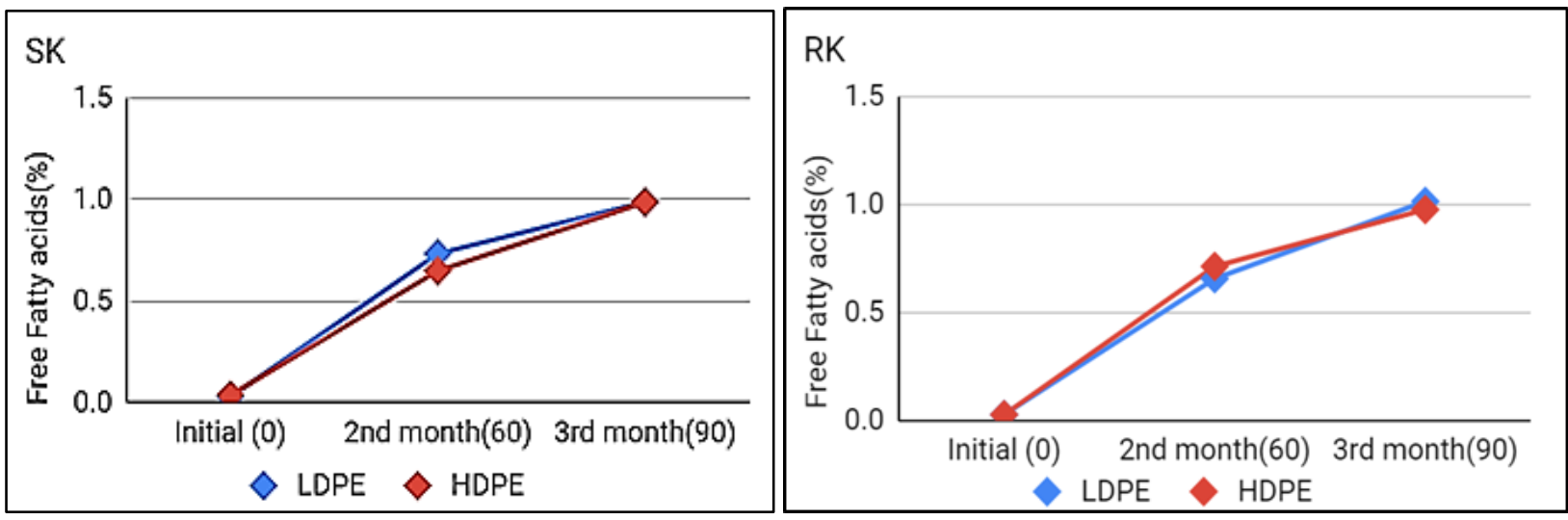

Fig 2: Free Fatty Acid Values (\%) of Khakhra on Storage

Peroxide value of the developed products from initial to 90 days of storage in different packaging material are as seen in Fig 3. Peroxide value increased with increase in days, it varied from 2.28 to 7.12 in LDPE and 2.28 to 6.4 (Meq $\mathrm{O}_{2} / \mathrm{Kg}$ ) in HDPE. Significant difference among packaging material on 90 days of storage was seen in sample FMK and
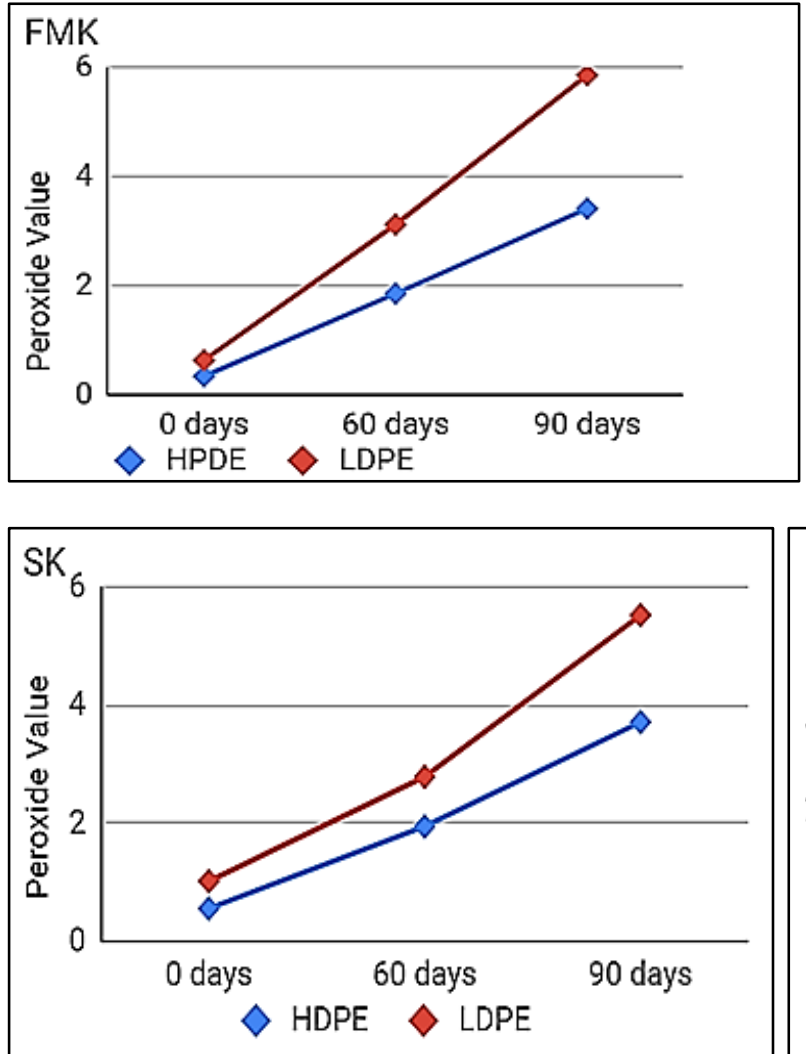

Fig 3. Peroxide Values (Meq $\mathrm{O}_{2} / \mathrm{Kg}$ ) of Khakhra on Storage

Table 4. denotes the microbial load of different varieties of khakhras stored in LDPE and HDPE for a duration on 90 days. There was no growth of any kind of microorganisms on initial to 30th day of storage of all samples packed in HDPE. But bacteria started to grow on 60th day in products stored in LDPE. Highest bacterial count was observed at 90 days in sample SK (LDPE) i.e.,86 CFU, which was well within the permissible limits. Significant difference among packaging
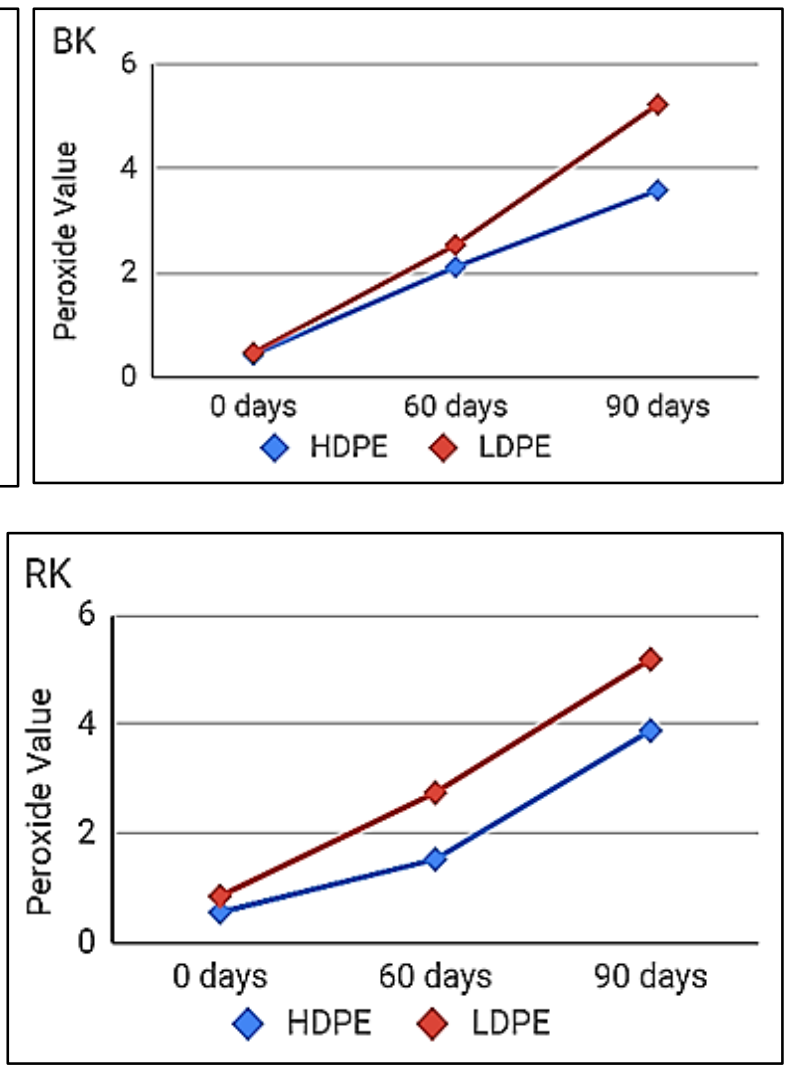

BK $(P<0.01)$. However, peroxide values in both the storage material were within acceptable range. Similar values for peroxide value $\left(0.59-7.4 \mathrm{Meq} \mathrm{O}_{2} / \mathrm{Kg}\right)$ were recorded in a shelf-life study of homemade extruded products formulated using pearl millet based composite flour ${ }^{[32]}$.

material was found $(P<0.05)$. However, E. coli was observed to be nil, and a bare minimum count of salmonella was seen. This may be attributed to the fact that khakhras have a low moisture content. Similar findings were observed in a study done on finger millet khakhra ${ }^{[33]}$. Thus, indicating that the khakhras could be safely stored in LDPE and HDPE for a period of 90 days. 
Table 4: Microbial load of stored khakhras

\begin{tabular}{|c|c|c|c|c|}
\hline Organism & Variation & & Duration in days & \\
\hline \multirow{9}{*}{$\begin{array}{c}\text { TBC } \\
\mathrm{X} 10^{3} \mathrm{CFU}\end{array}$} & & $\mathbf{0}$ & 60 & 90 \\
\hline & BK(LDPE) & 2 & $7.34^{\mathrm{a}}$ & $81.67^{a}$ \\
\hline & BK(HDPE) & 0 & 0 & $34.34^{\mathrm{b}}$ \\
\hline & SK(LDPE) & 0 & $7^{\mathrm{ab}}$ & $86^{\mathrm{a}}$ \\
\hline & SK(HDPE) & 0 & 0 & $26.34^{\mathrm{b}}$ \\
\hline & RK(LDPE) & 0 & $11^{\mathrm{ab}}$ & $82.34^{\mathrm{a}}$ \\
\hline & RK(HDPE) & 0 & 0 & $35.67^{\mathrm{b}}$ \\
\hline & FMK(LDPE) & 0 & $14.67^{\mathrm{ab}}$ & $77^{\mathrm{a}}$ \\
\hline & FMK(HDPE) & 0 & 0 & $44.34^{\mathrm{b}}$ \\
\hline \multirow{8}{*}{$\begin{array}{c}\text { E. coli } \\
\mathrm{X} 10^{4} \mathrm{CFU}\end{array}$} & BK(LDPE) & 0 & 0 & 0 \\
\hline & BK(HDPE) & 0 & 0 & 0 \\
\hline & SK(LDPE) & 0 & 0 & 0 \\
\hline & SK(HDPE) & 0 & 0 & 0 \\
\hline & RK(LDPE) & 0 & 0 & 0 \\
\hline & RK(HDPE) & 0 & 0 & 0 \\
\hline & FMK(LDPE) & 0 & 0 & 0 \\
\hline & FMK(HDPE) & 0 & 0 & 0 \\
\hline \multirow{8}{*}{$\begin{array}{l}\text { Salmonella } \\
\mathrm{X} 10^{2} \mathrm{CFU}\end{array}$} & BK(LDPE) & 0 & 0 & 0 \\
\hline & BK(HDPE) & 0 & 0 & 0 \\
\hline & SK(LDPE) & 0 & 0.5 & 0.34 \\
\hline & SK(HDPE) & 0 & 0 & 0 \\
\hline & RK(LDPE) & 0 & 0 & 0 \\
\hline & RK(HDPE) & 0 & 0 & 0 \\
\hline & FMK(LDPE) & 0 & 0.17 & 0.17 \\
\hline & FMK(HDPE) & 0 & 0 & 0 \\
\hline
\end{tabular}

Values are mean values of triplicate determination. Values in different superscripts indicate significant difference among samples on application of Tukey's Test (column).

\section{Conclusion}

Millets being nutritionally superior, climate compliant crops can be utilized in development of value added ready to eat products such as khakhras. From this study incorporation of different millets influenced the nutritional composition. Pearl millet incorporated khakhra showed highest antioxidant components and antioxidant activity. The storage quality parameters and microbial load were well within the permissible limit making the product shelf stable for up to 90 days. However, it is necessary to popularize these traditional ready-to-eat products among all sectors of the population and also as a functional food.

\section{Acknowledgements}

The authors thank University of Agricultural Sciences, GKVK, Bangalore; for allowing to carry on the research work.

\section{Reference}

1. Menrad K. Market and marketing of functional food in Europe. J Food Eng 2003;56:181-188. doi: 10.1016/S0260-8774(02)00247-9. [CrossRef] [Google Scholar]

2. Roberfroid MB. A European consensus of scientific concepts of functional foods. Nutr 2000;16:689-691. doi: 10.1016/S0899-9007(00)00329-4. [PubMed] [CrossRef] [Google Scholar]

3. Sloan AE. The top ten functional food trends. Food technology 2016, 24-45, https://www.ift.org

4. Slavin J. Whole grains and human health. Nutr. Res. Rev, 2004;17(1):99-110. doi:10.1079/NRR200374

5. Gopalan C, Rama Sastri BV, Balasubramanian SC. Nutritive Value of Indian Foods, Hyderabad: NIN, ICMR 2004, 27.

6. Guohua C, Eimin S, Ronald LP. Antioxidant and pro- oxidant behaviour of flavonoids. Structure activity relationships. Free Radic Biol Med 1997;22:749-60. http://dx.doi.org/10.1016/S0891-5849(96)00351-6

7. Siddiqui A, Prakash J. Dietary fiber and related antioxidant components from cereal sources and their role in health. Trends Carbohydr. Res 2014;6(1):1-19.

8. Wadikar DD, Kangane SS, Parate V, Patki PE. Optimisation of a Multi-millet ready-to-eat extruded snack with digestibility and nutritional perspective. Indian J Nutri 2014;1(1):104.

9. Pathania S, Kaur A, Sachdev PA. Chickpea flour supplemented high protein composite formulation for flatbreads: effect of packaging materials and storage temperature on the ready mix. Food Packag. Shelf Life 2017;11:125-132. doi: 10.1016/j.fpsl.01.006. [CrossRef] [Google Scholar] [Ref list]

10. Association of Official Analytical Chemists. Official methods of analysis.18th ed. Washington, DC 2005.

11. Ranganna S. Handbook of analysis and quality control for fruit and vegetable products 2nd ed, McGraw-Hill, New Delhi 2007.

12. Asp NG, Johansson CG, Hallmer H, Siljestroem M. Rapid enzymic assay of insoluble and soluble dietary fiber. J Agric Food Chem 1983;31:476-482.

13. Prieto P, Pineda M, Aguilar M. Spectrophotometric quantitation of antioxidant capacity through the formation of a phosphomolybdenum complex: Specific application to the determination of Vitamin E. Anal. Biochem 1999;269:337-341. http://dx.doi.org/10.1006/abio.1999.4019

14. Matthäus B. Antioxidant activity of extracts obtained from residues of different oilseeds. J Agric Food Chem, 2002;50:3444-3452. http://dx.doi.org/10.1021/jf011440s

15. Arvouet-Grand A, Vennat B, Pourrat A, Legret P. Standardisation d'un extrait de propolis et identification 
des principaux constituants [Standardization of propolis extract and identification of principal constituent. J. Pharm. Belg 1994;49:462-468.

16. Michelle RW, Helen CB. Food preferences of men and women by sensory evaluation versus questionnaire. Fam. Con. Res 2001;29(3):288-301.

17. Raguramulu N, Madhavan NK, Kalyana SS. A laboratory technique, NIN, ICMR publications., Hyderabad 2003.

18. Sanders ER. Aseptic laboratory techniques: plating methods. Journal of visualized experiments: JoVE 2012;(63):e3064. https://doi.org/10.3791/3064

19. Lakshmi Devi N, Shobha S, Tang X, Shaur S, Dogan H, Alavi S, et al. Development of protein-rich sorghumbased expanded snacks using extrusion technology, Int. J. Food Prop 2013;16(2):263-276.

DOI: $10.1080 / 10942912.2011 .551865$

20. Bhavya SN, Prakash J. Nutritional composition and quality of whole grain ready-to-eat breakfast cereals. Indian J Nutr Diet 2012;49;417-425.

21. Vanishri KU, Vijayalaxmi KG. Organoleptic, physical, nutritional characteristics and storage stability of value added Kodo masala khakhra, J. Pharmacogn. Phytochem 2020;9(5):326333.

DOI:https://doi.org/10.22271/phyto.2020.v9.i5Sf.12841

22. Bolarinwa IF, Olaniyan SA, Adebayo LO, Ademola AA. Malted sorghum-soy composite flour: preparation, chemical and physico-chemical properties. J Food Process Technol 2015;6:467. doi:10.4172/21577110.1000467

23. Marín L, Miguélez EM, Villar CJ, Lombó F. Bioavailability of Dietary Polyphenols and Gut Microbiota Metabolism: Antimicrobial Properties. BioMed Research International 2015, 18. https://doi.org/10.1155/2015/905215

24. Sevgi K, Tepe B, Sarikurkcu C. Antioxidant and DNA damage protection potentials of selected phenolic acids. Food Chem. Toxicol 2015;77:12-21. [CrossRef] [PubMed]

25. Tomás-Barberán FA, Andrés-Lacueva C. Polyphenols and health: current state and progress. J. Agric. Food Chem 2012;60:8773-8775. [CrossRef] [PubMed]

26. Zeng Z, Liu C, Luo S, Chen J, Gong E. The Profile and Bioaccessibility of Phenolic Compounds in Cereals Influenced by Improved Extrusion Cooking Treatment. PLoS ONE, 2016, 11. [CrossRef] [PubMed]

27. USDA Database for the Flavonoid Content of Selected Foods. 2014;3(1).

https://www.ars.usda.gov/ARSUserFiles/80400525/Data/ Flav/Flav_R03-1.pdf.

28. Yao LH, Jiang YM, Shi J, Tomás-Barberán FA, Datta N, Singanusong R, et al. Flavonoids in food and their health benefits, Flavanones in cumin, peppermint, Flavones in parsley, thyme and Flavonols in onions. Plant Foods Hum. Nutr 2004;59:113-122. doi: 10.1007/s11130-0040049-7. [PubMed] [CrossRef] [Google Scholar]

29. Nambiar VS, Sareen N, Daniel M, Gallego EB. Flavonoids and phenolic acids from pearl millet (Pennisetum glaucum) based foods and their functional implications. Functional Foods in Health and Diseases 2012;2:257-264.

30. Pushparaj FS, Urooj A. Antioxidant activity in two pearl millet (Pennisetum typhoideum) cultivars as influenced by processing. Antioxidants (Basel) 2014;3(1):55-66. https://doi.org/10.3390/antiox3010055.
31. Surekha N, Ravikumar NS. Development of value added khakhra from barnyard millet: Consumer acceptability, nutritional and shelf- life evaluation. Asian J. Home Sci 2014;9(1):60-65.

32. Gautam L, Gupta A. Study on Storage Stability of Different Homemade Extruded Foods Products Prepared by Using Malted Composite Flour. Nat Prod Chem Res 2017;5:264. doi: 10.4172/2329-6836.1000264

33. Pasumarthi G. Preparation and sensory evaluation of finger millet khakhra, J Food Sci Nutr Res 2019;2(1):061-064. 